\title{
Impact of COVID-19 on the labor market: case of Sonora, Mexico
}

\section{Impacto de COVID-19 en el mercado laboral: el caso de Sonora, México} ROSSETTI-LÓPEZ, Sergio Ramón†*, VERDUGO-TAPIA, María Leticia, ROJAS-RODRIGUEZ,
Isaac Shamir and MARTINEZ-VERDUGO, Juan Carlos

Universidad de Sonora, Administration Department Central Regional Unit, Mexico.

ID $1^{\text {st }}$ Author: Sergio Ramón, Rossetti-López / ORC ID: 0000-0002-5524-8674

ID $1^{\text {st }}$ Co-author: María Leticia, Verdugo-Tapia / ORC ID: 0000-0001-5594-5376

ID $2^{\text {nd }}$ Co-author: Isaac Shamir, Rojas-Rodríguez / ORC ID: 0000-0002-0798-1476

ID $3^{\text {rd }}$ Co-author: Juan Carlos, Martínez-Verdugo / ORC ID: 0000-0003-2181-1868

\begin{abstract}
This article identifies the impact that the COVID-19 contingency has had on the labor market in the state of Sonora in Mexico. Through a descriptive, crosssectional and quantitative study, based on microdata from the Telephone Survey on COVID-19 and the INEGI Labor Market for the state of Sonora. The main effects that workers have had during the pandemic and how they have coped with this period of crisis are described. The results show the great impact that has been had in the state and what is the outlook for the future.
\end{abstract}

\section{Resumen}

En este artículo se identifica el impacto que ha tenido la contingencia COVID-19 en el mercado laboral del estado de Sonora en México. Mediante un estudio descriptivo, transversal y cuantitativo, con base en microdatos de la Encuesta Telefónica sobre COVID19 y el Mercado Laboral del INEGI para el estado de Sonora. Se describen los principales efectos que han tenido los trabajadores durante la pandemia y cómo han afrontado este período de crisis. Los resultados muestran el gran impacto que se ha tenido en el estado y cuál es el panorama para el futuro.

\footnotetext{
* Correspondence to Author (Email: sergio.rossetti@unison.mx)

$\dagger$ Researcher contributing first author.
} 


\section{Introduction}

During the first months of 2020, the challenge of facing the pandemic caused by COVID-19 began in the Latin American countries, in an economic and labor situation characterized in the region by stagnation and slowing of improvements in the markets of job. To curb the spread of COVID-19, governments have put in place regulations requiring social distancing, non-essential business closings, travel restrictions, and in many cases even a curfew for people to stay home (Fetzer et al., 2020). Although these measures are necessary for public health and pandemic control, recent evidence from developed countries suggests that they have negative economic impacts in the short term (Adams-Prassl, Boneva, Golin, \& Rauh, 2020).

The COVID-19 pandemic has caused a major and unprecedented economic recession in the region. According to figures from the World Bank (2020) there is a record of an average collapse for the region of the order of $-7.2 \%$ of GDP for the year 2020, the highest figure in the last 70 years. Recent projections estimated by the International Monetary Fund (IMF, 2020) further exacerbate the contraction of GDP in the area, raising the figure to $-9.4 \%$, with drops of $11 \%$ in Mexico, $-9.1 \%$ in Brazil, 9.9\% in Argentina, $-7.5 \%$ in Chile, $-7.8 \%$ in Colombia and $-13.9 \%$ in Peru. One of the main repercussions caused by this health crisis has been an immediate collapse of the work and family income of a large number of people (ILO, 2020).

According to Bottan, Hoffmann, and Vera-Cossio (2020) in a study conducted in 17 developing countries, 45 percent of respondents reported that a household member lost their job and, among households with small family businesses, 58 percent of respondents reported that a household member closed their business. In this scenario of uncertainty in the course of the pandemic, it is difficult to predict when the economic recovery process will take place in the countries and to what degree the social distancing measures affected the labor market.
In this context, the closure of a considerable number of companies would not only lead to a deepening of concentration processes, a large number of formal jobs for people with intermediate levels of formal education would also be permanently eliminated, thereby intensifying said trend to concentrate the employment of this segment of the labor force in sectors of low productivity and the increase of the informal sector. Although telecommunications allow some jobs and businesses to migrate to teleworking, the digital divide and access to broadband Internet in Mexico make it difficult for many occupations to continue in the digital world (Sanchez et al., 2020). According to CONEVAL (2020), the crisis generated by the pandemic increased the levels of working poverty from $36 \%$ to $55 \%$ by May 2020.

According to the ILO, the sectors with the greatest impact are: manufacturing industries, wholesale and retail trade, real estate, lodging, as well as the food and beverage trade. The containment and social distancing measures that governments have had to implement worldwide have brought significant effects on the labor market and Mexico is no exception. Some companies have been affected to a greater and lesser extent. For example, formal micro and small companies are at a structural disadvantage due to the technological gap that has been registered between companies of different sizes in the context of digitization (Veugelers, Rückert and Weiss, 2019), which is why it has been suggested that the promotion of the use of digital technologies in companies should place emphasis on smaller companies (ECLAC-ILO, 2020).

In this sense, labor markets have been impacted at different levels of intensity according to economic activity. However, within each sector a heterogeneity of situations has been verified depending on the activity in which the workers are found (ILO, 2020). For example, the accommodation, commerce and food sectors have been among the most affected and, therefore, workers are in a vulnerable situation to possible cuts in wages, personnel or working hours. On the other hand, in areas such as public administration, education and health, there has been little impact or even in some cases, activity has been maintained or increased. 
Social distancing measures may permanently change the nature of work through job reallocation and changes in occupational structures (Baldwin, 2020).

Derived from the impact that COVID-19 has had in Mexico, the temporary suspension of censuses and surveys to be carried out in the national territory was published in the Official Gazette of the Federation where the mobilization of people and physical interaction are involved. With this, the National Institute of Statistics and Geography (INEGI) designed alternative methods for gathering information. From there arises the Telephone Survey on COVID-19 and Labor Market (ECOVID-ML), which has the purpose of offering basic and relevant information on the effect of the health contingency in the labor market and in this way, offering timely information to public decision makers in Mexico.

As of April 2020, the INEGI portal publishes the national results report on ECOVID-ML, however, there is no official statistical summary that presents the panorama of the impact of COVID-19 for the state of Sonora. Hence the need to process and analyze the open data available on the INEGI portal, to know the impact that the COVID-19 contingency has had on the Labor Market at the state level and in this particular case, in Sonora.

According to figures for the third quarter of 2020 (INEGI, 2020), in the state of Sonora, Mexico there is an occupancy rate of $54.3 \%$ with respect to the economically active population, that is, about 1,222,712 people in employment. . Likewise, there is an unemployment rate of $6.7 \%$, a figure above the national level of $5.1 \%$, a wage-earning rate of $74 \%$, similarly higher than the national level of $65.6 \%$. There is also an informal occupation rate of $19.7 \%$, lower than the national one of $26.8 \%$. Regarding the critical occupancy conditions rate, in Sonora there is $19.8 \%$ and at the national level $23.9 \%$.

The results of this study may be useful to know the repercussions on the labor market of the state of Sonora, derived from the public mitigation policies implemented by the government.

\section{Methodology to be developed}

As a methodological technique for this research, a quantitative cross-sectional methodology was selected. The scope of the study is descriptive, because the information collected is intended to explain the facts without altering them, for which the research variables are measured to be able to describe them in the desired terms (Hernández-Sampieri and Torres, 2018).

\section{General purpose}

Identify the impact that the COVID-19 contingency has had on the Labor Market in the state of Sonora.

\section{Temporal delimitation}

The data collected for this research comes from the microdata of the Telephone Survey on COVID-19 and the Labor Market (ECOVIDML) for the months of May, June and July 2020 published on the INEGI portal.

\section{Study population and sample}

The study population is limited by the telephone number sampling frame of the National Numbering Plan of the Federal Telecommunications Institute (IFT) used in ECOVID-ML. From this framework, only the sample collected for the Sonora state was selected. The informants were people 18 years of age or older, in addition, telephone users. In this regard, the following data is available in accordance with INEGI (2020).

Total population: $126,852,639$.

Population aged 18 and over: 89,718,293.

Telephone user population aged 18 and over: $68,184,430$.

Type of sampling: random.

Type of survey: telephone.

National ECOVID-ML sample size: May 11,586, June 13,908 and June 14,458.

Sample size ECOVID-ML Sonora: May 278, June 330 and June 325. 


\section{Results}

This section presents the results of the investigation. First, a description of the sample is made and later, the tables and graphs of the responses obtained through the ECOVID-ML telephone survey on the impact that COVID-19 has had on the labor market in Sonora are presented. As can be seen in graph $1,55 \%$ of the respondents were men and $45 \%$ women.

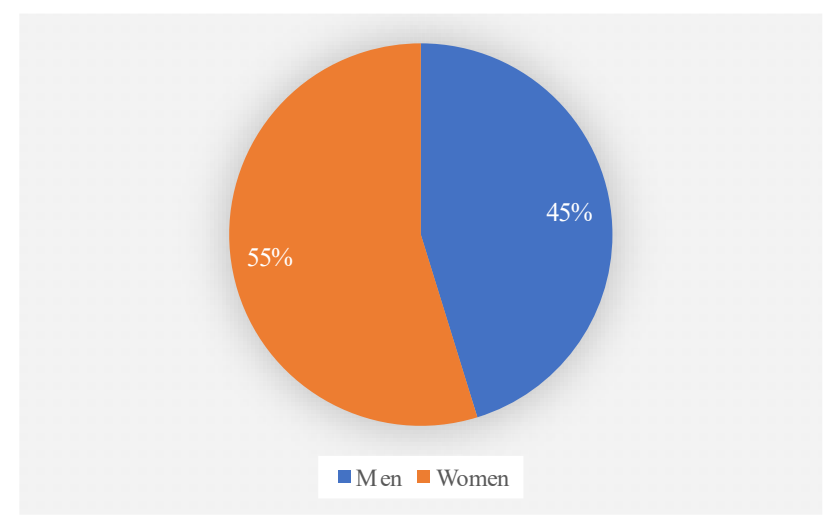

Graphic 1 Distribution by gender of the sample

Source: Own elaboration based on ECOVID-ML

Table 1 presents the descriptive statistics for the age variable of the subjects responding to the survey for the state of Sonora. As can be seen, the average age of the subjects was 44.41 years and the age range was from 18 to 90 years.

\begin{tabular}{|r|r|r|}
\hline Minimum & \multicolumn{1}{c}{ Maximum } & Average \\
\hline 18 & 90 & 44.41 \\
\hline
\end{tabular}

Table 1 Descriptive of the age variable Source: Own elaboration based on ECOVID-ML

Regarding the type of occupation carried out by the subjects at the time of the survey, in Graphic 2 it is observed that regardless of the month of the interview, the majority were in employment when observing percentages of $45.30 \%, 42.70 \%$ and $43.40 \%$ for the months May, June and July respectively. Likewise, there is a decrease in the percentage of people who had a business, going from $4.70 \%$ to $2.20 \%$ during the months from May to July. Also in the occupation of people on their own, a decrease is observed, going from $12.20 \%$ to $10.40 \%$. As for no occupation, an increase is observed, going from $37.80 \%$ to $44.00 \%$ from May to June.

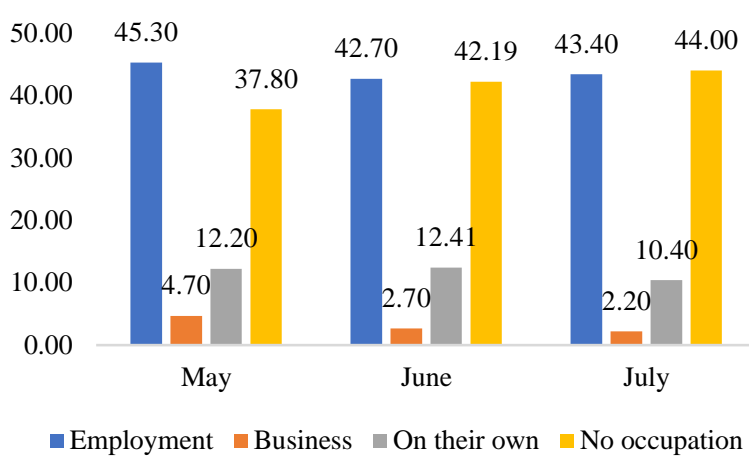

Graphic 2 Occupation of respondents Source: Own elaboration based on ECOVID-ML

Regarding the question about what is the main problem facing your business or activity today? As can be seen in Table 2, most of the respondents responded mainly to the option of being affected by COVID-19 with $35 \%$ in the month of May, 49\% in June and 30\% in July.

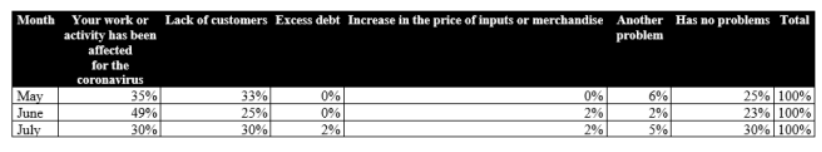

Table 2 Main problem facing your business or activity Source: Own elaboration based on ECOVID-ML

Regarding the people who answered that they had some kind of problem in their activity or business, Table 3 shows the way in which they have dealt with the problem. An upward trend and greater concentration is observed towards the solution of the implementation of services through the internet either in an app or website, going from $17 \%$ in May, to $20 \%$ in June and $33 \%$ in July. It is noteworthy that the dismissal of workers has been the solution implemented for $3 \%$ in May, $2 \%$ in June and 3\% in July.

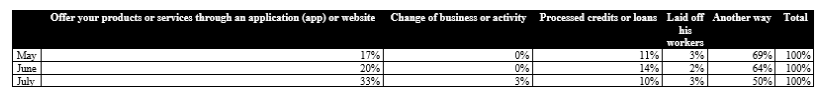

Table 3 How they have dealt with the problem Source: Own elaboration based on ECOVID-ML

One of the questions has to do with whether the person worked from home due to the contingency the week before the survey, in Graphic 3 it is observed that most of the people answered that they did not work from home with $81 \%$ for the months May and June, and $85 \%$ in July. 


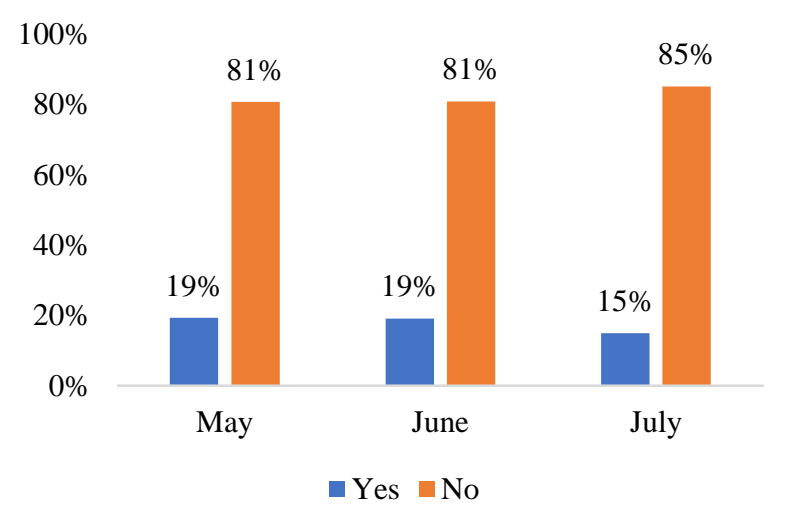

Graphic 3 Worked from home for COVID-19 Source: Own elaboration based on ECOVID-ML

Regarding whether the contingency caused by COVID-19, the people who worked have seen their hours or working hours affected, in Graphic 4 it is observed that it remained the same for $40 \%$ in May, $45 \%$ in June and $51 \%$ in July. It decreased to $37 \%$ in May, 38\% in June and $35 \%$ in July. And there was an increase to $4 \%$ in May, $5 \%$ in June and $8 \%$ in July.

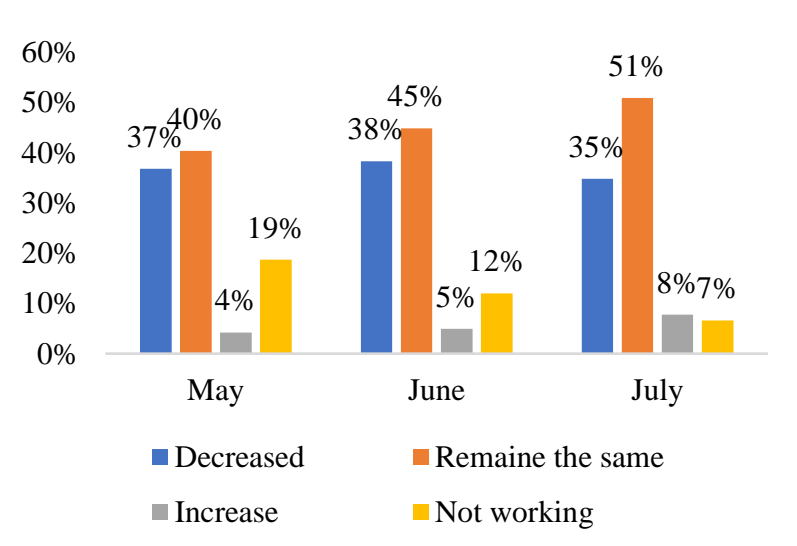

Graphic 4 Impairment of working hours by COVID-19 Source: Own elaboration based on ECOVID-ML

A relevant question has to do with any of the months from May to June, a member of their household lost their job or closed their business due to the contingency due to the coronavirus or COVID-19, in Graphic 5 it is observed that the $30 \%$ of the people stated that they had a member of the household with a job loss due to the contingency. $70 \%$ stated that they did not have a member affected in this regard.

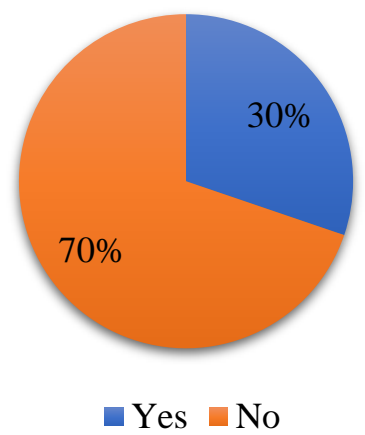

Graphic 5 Some member of the household lost their job due to COVID-19

Source: Own elaboration based on ECOVID-ML

Graphic 6 presents the results obtained for the question Has your household income decreased due to the contingency caused by the coronavirus or COVID-19? It is observed that $62 \%$ of people have not had a decrease in income and $38 \%$ if they have faced monetary reductions due to the contingency.

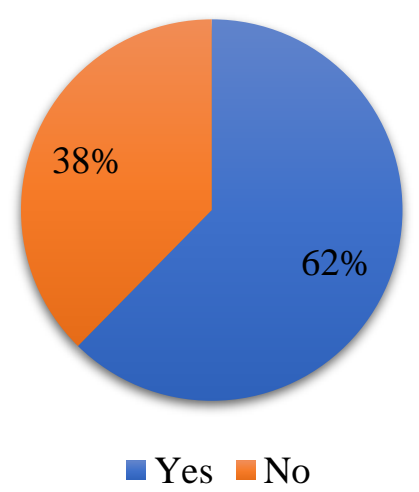

Graphic 6 Household income has decreased due to COVID-19

Source: Own elaboration based on ECOVID-ML

Finally, Graphic 7 shows the percentages of responses to the previous question by level of studies. Although a great impact is observed in general regardless of the level of studies of workers in the state of Sonora, there is a trend towards a lower proportion of affectation towards people with a higher level of education, going from $67 \%$ for those with higher education level basic, $65 \%$ for intermediate level and $51 \%$ for higher level. 


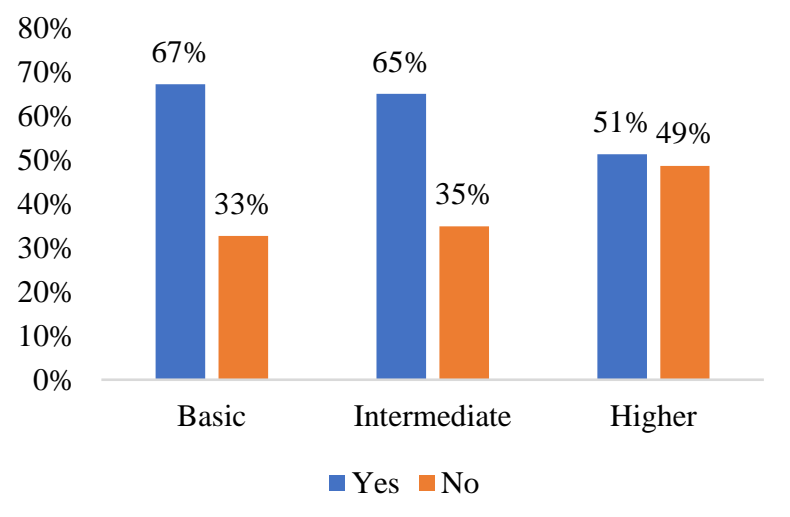

Graphic 7 Decrease in income by educational level Source: Own elaboration based on ECOVID-ML

\section{Conclusions}

The coronavirus pandemic represents a great challenge for the labor market in Sonora and other regions of the world. As evidenced in the statistics presented in this study, Sonora's labor market has been greatly affected in the short term by the social distancing restrictions implemented by decision makers during the pandemic. Reduction in family income, loss of jobs and business closures have occurred in Sonora. Repercussions caused by social distancing measures that are consistent with what was stated by Adams-Prassl, Boneva, Golin, and Rauh, 2020. Likewise, there is a positive trend of companies towards the implementation of sales strategies and online work for to survive. It will be the work of governments to implement policies aimed at seeking the digitization of companies, prioritizing those with more limitations such as Micro, Small and Medium Enterprises. As the world and business return to normal, employers will have to decide what kinds of business models to develop from now on and what kinds of workforce they will require. On the other hand, the results of the study have been able to verify that people with a lower level of education have been the most affected by COVID-19, with a decrease in income in a greater proportion compared to people with higher education. This is attributable to the fact that generally people with a lower level of education occupy manual positions or jobs that can hardly be transferred to the online mode. This causes a reduction in the hours of the working day and in other cases, the request for employment. It will be a challenge for governments to create policies to support this and other sectors so affected by COVID-19.

\section{References}

Adams-Prassl, A., Boneva, T., Golin, M., y Rauh, C. (2020). Inequality in the impact of the coronavirus shock: Evidence from real time surveys.

Banco Mundial (2020). Perspectivas económicas mundiales. June 2020. Washington, DC, Banco Mundial.

Baldwin, R. E. (2020). Covid, hysteresis, and the future of work. Recovered from https://voxeu.org/article/covid-hysteresis-andfuture-work

Bottan, N., Hoffmann, B., y Vera-Cossio, D. (2020). The unequal impact of the coronavirus pandemic: Evidence from seventeen developing countries. PLoS ONE. https://doi.org/10.1371/journal.pone.0239797

CEPAL-OIT (2020) Coyuntura Laboral en América Latina y el Caribe. El trabajo en tiempos de pandemia: desafíos frente a la enfermedad por coronavirus (COVID-19), Coyuntura Laboral en América Latina y el Caribe, Nro. 22, Santiago.

CONEVAL. (2020). Ante la crisis sanitaria por la Covid-19, el Coneval presenta información referente a la pobreza laboral con la Encuesta Telefónica de Ocupación y Empleo (ETOE). COMUNICADO No.17.

Fetzer, T., Witte, M., Hensel, L., Jachimowicz, J., Haushofer, J., Ivchenko, A., ... Fiorin, S. (2020). Global behaviors and perceptions in the COVID-19 pandemic.

Fondo Monetario Internacional (FMI) (2020). "La COVID-19 en América Latina y el Caribe: Una fuerte factura en vidas y medios de vida", Perspectivas económicas: Las Américas. Estudio de referencia No. 1, DC, octubre.

Hernández-Sampieri, R., \& Torres, C. P. M. (2018). Metodología de la investigación (Vol. 4). México ed. F DF: McGraw-Hill Interamericana. 
INEGI. (2020). Resultados de la encuesta nacional de ocupación y empleo. Nueva edición (enoen) cifras durante el tercer trimestre de 2020. Septiembre, 1-14. Recovered from https://www.inegi.org.mx/contenidos/programa s/enoe/15ymas/doc/enoe_n_nota_tecnica_trim3. pdf

OIT. (2020). Impactos en el mercado de trabajo y los ingresos en América Latina y el Caribe. Organizacion Internacional del Trabajo, 1-23. Recovered from https://www.ilo.org/wcmsp5/groups/public/--americas/---ro-

lima/documents/publication/wcms_749659.pdf

Sanchez, D. G., Parra, N. G., Ozden, C., Rijkers, B., Viollaz, M., y Winkler, H. (2020). Who on earth can work from home? Development Research..
ROSSETTI-LÓPEZ, Sergio Ramón, VERDUGO-TAPIA, María Leticia, ROJAS-RODRIGUEZ, Isaac Shamir and MARTINEZVERDUGO, Juan Carlos. Impact of COVID-19 on the labor market: case of Sonora, Mexico. Journal of Administration and Finance. 2020 